International Journal of Social Science (IJSS)

Vol.1 Issue.5 February 2022, pp: 601-608

ISSN: 2798-3463 (Printed) | 2798-4079 (Online)

\title{
GOVERNMENT POLICY OF THE CITY OF BANJARMASIN ON REDUCING THE USE OF PLASTIC BAGS (A CASE STUDY OF A GOVERNMENT POLICY OF THE CITY OF BANJARMASIN)
}

\author{
By \\ M. Sayuti Enggok ${ }^{1}$, Normajatun², Deli Anhar ${ }^{3}$ \\ 1,2,3 Kalimantan Islamic University of Muhammad Arsyad Al-Banjari, Faculty of Social and Political Sciences, Banjarmasin, \\ Indonesia. \\ Email: ${ }^{1}$ msayutienggok@gmail.com
}

\begin{tabular}{l}
\hline \hline Article Info \\
\hline Articlehistory: \\
Received Nov 12, 2021 \\
Revised Dec 23, 2021 \\
Accepted Jan 21, 2022
\end{tabular}

Keywords:

Policy, public, Implementation, Plastic, Bag, Waste.

\begin{abstract}
This study aims to determine the implementation of Banjarmasin city government policies in reducing the use of plastic bags in traditional markets in the city of Banjarmasin. This study uses a qualitative approach with a descriptive analysis method. As a key informant, the Head of the Sanitation and Waste Management Office of the Banjarmasin City Environmental Service has been interviewed to collect data. To complete the data, we also interviewed both sellers and buyers in the markets of Pandu and TelukDalam Banjarmasin City. The results showed that the city government had implemented the policy through a socialization program in communication and transmission. The socialization program has been implemented in almost all the markets owned by the Banjarmasin city of government. Through the socialization program, we were found that the implementation of the policy was clear and consistent. The Banjarmasin City Environmental Service apparatus is the human resource involved in implementing the policy. The other resources came from the Banjarmasin City Regional Revenue and Expenditure Budget in budget sources. In terms of disposition, policy implementers are committed to carrying out their duties properly and democratically. The existence of Standard Operating Procedures has guided the policy implementation in terms of bureaucratic structure. However, implementation constraints still exist, such as public response, including the general understanding of the policy's benefits to reduce the use of plastic bags.
\end{abstract}

Thisisan open accessarticleundertheCC BY-SAlicense.

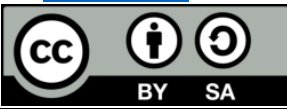

\section{CorrespondingAuthor:}

M. Sayuti Enggok,

Kalimantan Islamic University of Muhammad Arsyad Al-Banjari,

Faculty of Social and Political Sciences, Banjarmasin, Indonesia.

Email: msayutienggok@gmail.com

\section{INTRODUCTION}

The issue of global warming and the environment, especially regarding plastic waste, has become one of the most urgent global problems. The overuse of plastic products is a crucial issue. The seriousness of the use of plastic products will disrupt and contribute to the ecosystem and the destruction environment. The potential for damage to ecosystems and the environment contributed by plastic waste indirectly affects various aspects of people's lives in the agricultural sector.

Global warming makes, among others, the length of the dry season, besides too potentially makes of forest and land fires. The long dry season also disrupts the duration of farming. Although plastic waste is not the sole cause of global warming and environmental damage, efforts to prevent and even resolve plastic waste are necessary to solve global warming and environmental problems.

Based on the data, plastic waste in Indonesia's oceans is approximately 187.2 tons per year (Jambeck et al. 2015), making Indonesia the second largest plastic waste contributor after China. The sea is the most significant trash can; a place to accommodate $80 \%$ of the waste produced by humankind, and $90 \%$ of the garbage thrown into the sea comes from plastic waste, primarily plastic bags. While currently, the City of Banjarmasin volume waste produced 
per day reached 2,100 tons or 766 thousand tons a year. Of that number $14 \%$ is plastic waste is estimated at 295.6 tons per day or 107 thousand tons a year. This amount of waste will undoubtedly continue increases with an increasing number population. In 2019, data on waste management released by the Banjarmasin City Government shows, among other things, that the number of new waste management reached $68.89 \%$ with a figure of a reduction only $19.66 \%$. Thus more or less $30 \%$ of waste production has not been handled.

So far, based on experience, it teaches that the control of plastic waste, especially those from plastic bags, will not work without the suitable policy instruments and are coercive in an effectively and persistently manner (Haroan, 2010 in Saraswati, 2018). Therefore, the Government of Indonesia through, the Ministry of Environment and Forestry 2016, has launched the Declaration of Waste Care to build mutual awareness between the Government, society and, the world to drive the 3Rs (Reduce, Reuse, Recycle) (Ekawati, 2016). In addition, a letter from the Director-General of Waste, Waste and Hazardous Toxic Management Number S.1230/PSLB3-PS/2016 concerning Prices and Mechanisms for Paid Plastic Bag Applications has implemented a policy regarding the plastic bag diet. This policy has been piloted in 22 cities in Indonesia.

Responding to the policies of the Indonesian Government, especially the 3R program with Reduce, Reuse, Recycle plastic, the Banjarmasin City Government issued a policy through the Banjarmasin Mayor Regulation Number 18 of 2016 concerning Reducing the Use of Plastic Bags.

The said Banjarmasin Mayor's policy is intended to change people's mindsets. People are asked not to depend on plastic bags that tend to damage the environment and replace them with bags made of paper or cloth that they can use repeatedly. Most importantly, it is environmentally friendly.

Implementation of a policy is a necessity to achieve the goal of establishing a policy. According to Grindle (1980), the implementation task is to form the linkages that will facilitate the realization of the objectives of a policy and the impact of government activities. Therefore, the study of implementation is included as a policy delivery system.

In terms of location, the implementation of the policy of reducing the use of plastic bags in the City of Banjarmasin starts from modern shopping centers, supermarkets, and minimarkets, and retail stores. According to data from the Banjarmasin City Environment Service in 2019, it showed that implementing this policy was very effective because it succeeded in reducing plastic waste by up to 55\%. Furthermore, the policy will also apply to the school environment, followed by an appeal to reduce plastic bags for restaurants, pharmacies, kiosks, shops, and the like.

The City of Banjarmasin government is aware that the mindset of most actors in the traditional markets are heterogeneous and different to the actors in the modern needs and or store, so the enforcement of the will apply policy especially to the traditional markets will be applied gradually.

For the first step, two markets, e. i.Pandu, and TelukDalam was targeted as the trial locations for implementing a plastic bag reduction policy.

As it is known that a market is a place where people trade goods and services, there is an interaction between the actors of producers and consumers and distributors of goods and services (Ehrenberg \& Smith, 2003 in Hartono et al., 2015: 838). Meanwhile, traditional markets are the largest source of waste producers in developing countries (Matsui et al., 2014). The city of Banjarmasin itself has 33 traditional markets with different scales. Some stalls produce various types of waste from merchandise, containers, and packaging made of plastic or paper in these traditional markets.

Incidentally, in November 2019, the Research team observed the buying and selling transaction process at the markets of Pandu and TelukDalam. Most of the actors who carry out buying and selling transactions at those two markets still use plastic bags to carry the commodities being transacted. Only one to two actors are seen carrying containers of non-plastic materials (such as baskets of Purun). Thus, it can state that the public, both sellers and buyers, still take a practical attitude in transactions. This is what makes dependence on plastic bags still show at a significant level. Becker et al. (2014) argue that individual intentions are less potent when compared to habits and institutional regulations, incentives, and supports that can encourage behavior change by changing the values and goals of behavior. Bans or taxes on plastic bags are examples of rules that can use.

The Banjarmasin City Government has made a policy to reduce the use of plastic bags, but most people, especially the actors in traditional markets, have not complied with the procedure. Meanwhile, this situation pushes the Research Team to conduct research that focuses on reducing or prohibiting plastic bags in traditional markets. As well as the fact that the research which focuses on the policy implementation on reducing or banning the use of plastic bags at the traditional markets were still scarce and limited.

\section{METHODS}

This research uses a qualitative approach with descriptive analysis. 
International Journal of Social Science (IJSS)

Vol.1 Issue.5 February 2022, pp: 601-608

ISSN: 2798-3463 (Printed) | 2798-4079 (Online)

Data was collected through interviews with Marzukias the Head of Sanitation and Waste Management at the Banjarmasin City Environmental Service as key informants. In completing data, interviews were conducted with each seller and buyer who accidentally met and chose at the markets of Pandu and Teluk Dalam in the city of Banjarmasin.

\section{RESULTS AND DISCUSSION}

The Banjarmasin city government implemented reducing plastic bag use in the traditional markets in Banjarmasin City in early 2019. The policy of reducing plastic waste in conventional markets is crucial and significant. Anyhow, the policy reducing plastic waste is not only part of the role of the Banjarmasin City Government in handling waste both on land, in the waters, as well as those related to river restoration, as well as to maintain the Adipura title as until currently have been awarded to the Government of Banjarmasin City.

Implementing a public policy is an action taken by the government, especially the authorized agent, to overcome or solve a problem in society's lives.

To describe the actions taken by the Government of Banjarmasin City to overcome the problem of waste, especially plastic bags in the traditional markets, the description and analysis of this study uses the reference model of policy implementation from George Edward III which, are includes the factors of communication, resources, dispositions, and bureaucratic structure.

A. Communication.

The purpose of communication implementing a policy is to ensure that what is conveyed by policymakers can be known and understood by policy implementers so that the goals and objectives of the procedure can be too appropriately implemented to the target group of the concerned policy. The success of communication in implementing policies regarding reducing the use of plastic bags by the Government of Banjarmasin City needs to be discussed from three aspects: transmission, clarity, and consistency.

A sound transmission will result in exemplary policy implementation. A Good message will make policy implementers understand well the aims and objectives of the policy. In turn, the policy implementers will well implement the concerned policy too. The transmission to implement the Mayor of Banjarmasinapproach to reduce the use of plastic bags, especially in the traditional markets, used the form of socialization activities.

As stated by Marzuki as the Head of the Sanitation and Waste Management Division of the Environment office the City of Banjarmasin, that the socialization of reducing the use of plastic bags, especially in traditional markets, was carried out in several markets owned by the Government of the city of Banjarmasin : There are several markets in Banjarmasin that have been targeted, especially the markets belonging to the City Government that have been carried out, such as; TelukDalam, Pandu, Cemara Ujung, Pekauman, Telawang, Kalindo, and Pelambuan.

The target of the socialization activity is the group of merchant and the buyer.

The researcher interviewed Salamah as one of the merchants at TelukDalam Market and got the information: Yes, that's right, there was a socialization event at TelukDalam Market and at that time attended by the Mayor, Deputy Mayor, and there were also some other officials.

Likewise, at the Market of Pandu, socialization has also been carried out, as explained byTaufiq, one of the merchants: Several city government officials came to Pandu Market and explained reducing plastic bags so that they can replace with purun baskets.Purun is known as Eleocharisdulcis.

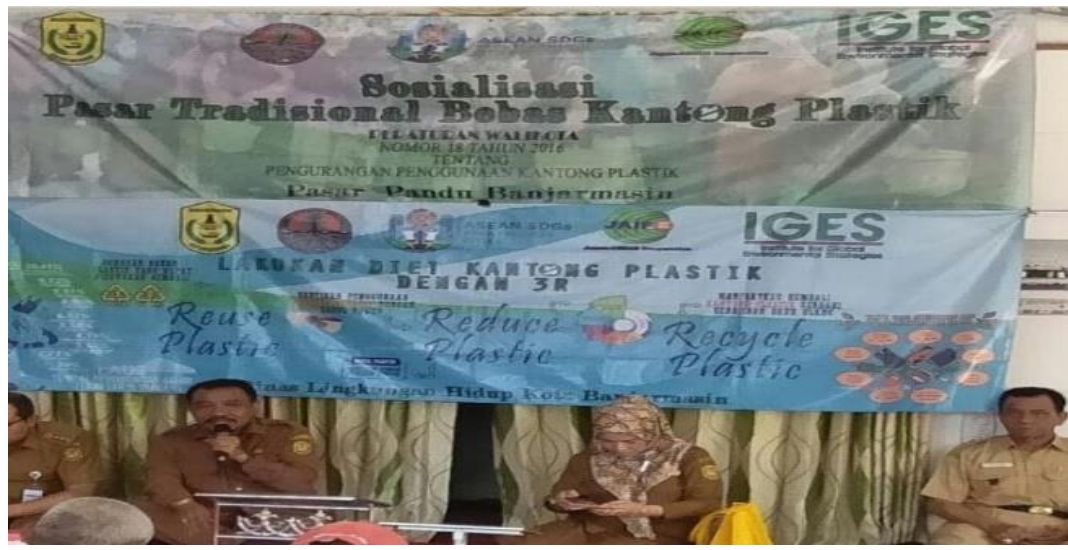

Fig1.Socialization Activities by the Banjarmasin City of Environment Office. 
Several forms of socialization which carried out by the Government of the city of Banjarmasin as disclosed byMarzuki as the Head of the Sanitation and Waste Management Division of the Environment office the City of Banjarmasin: The form of socialization during the socialization event, we appeal buyers to bring shopping bags other than plastic bags. At the socialization event, we then give purun baskets to those who present the event as a substitute for plastic bags. As for the merchants, we give directions. So far, for example, those who buy vegetables and spices are given their respective plastic bags, so it is recommended to replace them by combining vegetables and other ingredients that the buyer has purchased into one container. The point is not to prohibit but to reduce.

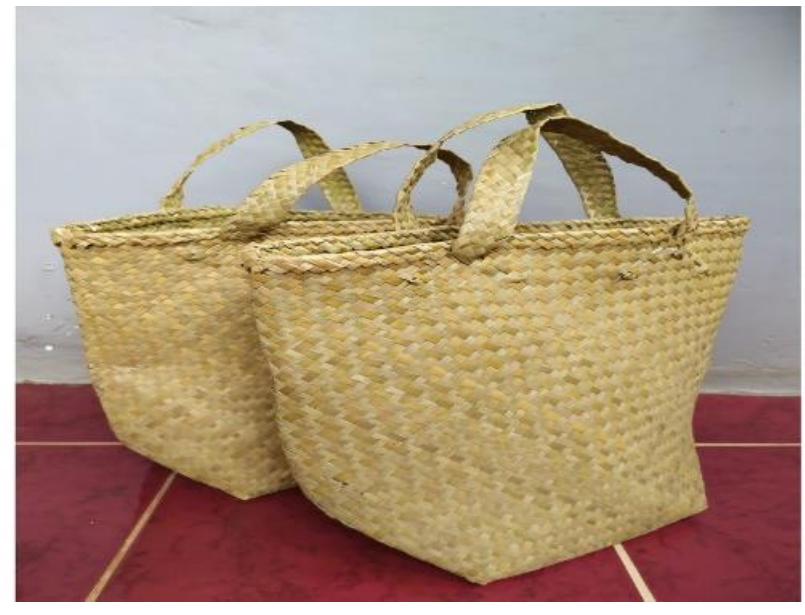

Fig2.PurunBag made from Purun (Eleocharisdulcis)

In communication, one must pay attention to the clarity of the message conveyed by both the communicator and the communicant. Concerning reducing plastic bags, an announcement of policy must be understood by both the implementer and the target community. Marzuki as The Head of the Sanitation and Waste Management Division of the Environment office the City of Banjarmasin disclosed that: Our Team, of course, already understands the Mayor's policy related to reducing the use of plastic bags. Because the Mayor briefed the team members and explained the intent and purpose of the regulations, this socialization activity is simple, just making a narration because the implementers already understand their duties.

Regarding the understanding of the material content presented by the Socialization Team, Abdul Halim one of the buyers at TelukDalam Market stated: For myself, of course, understood the regulations for reducing plastic bags, because I participate in the socialization. Almost the same answer was also given by another buyer at TelukDalam Market: I was also attending socialization activities carried out by the city government. I understand the appeal of the city government. Those of us attending were given the purun baskets.

When asked the same question toMasniah as the buyers at Pandu Market, the answer was: Regarding reducing plastic bags, I understand, we were asked to tell our family and neighbours. We will do that. Similarly, the answer from another buyer at Pandu Market stated: "I just learned that there was an appeal from the city government. Of course, we will support it.

Consistent means fixed or not changing. Consistency in a policy to avoid confusion for the implementers. The thickness of the policy of Mayor's of Banjarmasin on reducing the use of plastic bags was revealed byMarzuki, The Head of the Sanitation and Waste Management Division of the Environment office the City of Banjarmasin: In carrying out socialization activities, for example, when we are about to go down to the targeted market, the Team already have a reference. So the material we convey is the same for all the target markets. The point is to reduce the use of plastic bags, and we too distribute purun baskets, but the number of purun baskets is not the same for each market depending on the size of the market itself.

From a communication factor point of view, the implementation of reducing the use of plastic bags by the Government of the City of Banjarmasin, especially from the transmission side, has been done through socialization activities in almost all markets owned by the Government of the City of Banjarmasin. During socialization, besides conveying material about reducing plastic bags, they also distributed purun baskets to the buyer's community groups. Based on the terms of clarity and consistency, the government's policy on reducing plastic bags is clear and consistent.

B. Resources

Resources are needed to ensure the implementation of the policy run as planned. 
International Journal of Social Science (IJSS)

Vol.1 Issue.5 February 2022, pp: 601-608

ISSN: 2798-3463 (Printed) | 2798-4079 (Online)

DOI: https://doi.org/10.53625/ijss.v1i5.1302

All existing resources are expected to support policy implementation. Otherwise, lacking the required resources will affect policy implementation, which it cannot run as expected. The resources of implementation of the policy of reducing the use of plastic bags based on the resources consist of human, budgetary and facilities.

The human resources involved in implementing policies to reduce the use of plastic bags in traditional markets in the City of Banjarmasin, as stated by Marzuki, The Head of the Sanitation and Waste Management Division of the Environment office the City of Banjarmasin: All parties involved in the implementation of the policy of reducing plastic bag waste are officials from the Office of Environment Service, Market Sector of the Industry and Trade Office, the District Office as well as the Village Office. They are all as the implementers of the said policy.

Meanwhile, the budget resources for implementing the policies to reduce the use of plastic bags in traditional markets are specifically sourced from the Budget of the City of Banjarmasin, besides coming from the donors of third parties. Detail, as conveyed byMarzuki, the Head of the Sanitation and Waste Management Division of the Environment office the City of Banjarmasin: The special budget is sourced from the Budget of the City of Banjarmasin, as well as from donations of the third parties from "CSR" of a company based in the City of Banjarmasin. The funds sourced from the budget are mainly used to buy purun baskets which are distributed to the public in the targeted markets. Furthermore, he said: The available budget, of course, can be said to be not optimal. If you want it bigger than what we have now, but as you know, Budget of the City Government's is not only to handle one activity, so it must be adjusted to the ability of the City. This budget is sustainable, which mean it will not stop. It will continue. Because its success every year, the increase is still small.

Besides human resources and budget, the facilities needed to carry out the activities are vehicles. Regarding vehicle facilities, according to Marzuki, the Head of the Sanitation and Waste Management Division of the Environment office, the City of Banjarmasin: The only vehicles facilities needed are official cars. This facility is already sufficient.

Thus, it can be stated that from the resource factor, the first human resources involved in the implementation of the policy to reduce the use of plastic bags as implementers are the Environment Service, the Market Division of the Industry and Trade Office, as well as from the District and as well as the Village.

Second, the budget resources are sourced from the Budget of the City of Banjarmasin, and in addition, from donors as the third parties. Likewise, the means of motorized vehicles provided by the Government of the City of Banjarmasin are already enough.

C. Disposition

The implementation of the policy to reduce the use of plastic bags in traditional markets requires commitment as well as a democratic attitude from the implementers.

Concerning the commitment of the implementers as stated by Marzuki, the Head of the Sanitation and Waste Management Division of the Environment office the City of Banjarmasin: The task of implementing the mayor's policy is part of the duties of the state civil apparatus, so of course they have the responsibility and commitment to do their duties properly. This can be seen from the presence of the implementers starting from the meeting with the mayor until the implementation activities in the targeting markets. Regarding democratic attitude, furtherly, he explains: The implementers must have a democratic attitude, not sacred. We can't force it because the name of the program is socialization, so it's an appeal there's no sanction, it's voluntary from the community, so the expectation is public awareness itself.

Regarding incentives, Edward III stated that one of the suggested techniques to overcome the problem of the tendency of the implementers is to manipulate the incentives. In general, people act in their own interests, so the manipulation of incentives by policymakers influences the actions of policy implementers. When the researcher asked, were the implementers of the mayor's regulation given incentives? Then Marzuki, the Head of the Sanitation and Waste Management Division of the Environment office, the City of Banjarmasin, gave an explanation: There is no special incentive for the implementers because it is part of their duties as state civil servants. Except as a speaker, they will be paid as a travel fund. In nowadays, in the employee performance system, there is an application. Called "TUKIN" (Performance Allowance). So each member of the Activity Implementation Team records all their own activities, then input them by themselves to the application, such as the day, date and time of the activities that have been done. Then it will be verified by their superiors, and given the allowances.

Based on the disposition factor, policy implementers already have a commitment to do their duties well. The implementers also have a democratic attitude because the socialization activities are appeals, there are no sanctions. Implementers cannot force. Otherwise, it requires awareness from the community, both merchants and buyers in the traditional markets. In the socialization of policies to reduce the use of plastic bags, the implementers were not given incentives because it was their duty as the state civil servants. But given a reward in the form of performance allowances.

Journal homepage: https://bajangjournal.com/index.php/IJSS 


\section{Bureaucratic Structure}

The Bureaucratic structure is the parties involved in implementing the policy.One important aspect of the bureaucratic structure is the existence of Standard Operating Procedures or SOPs. SOPs serve as guidelines for every policy implementer in taking action. In the bureaucratic structure, there is a leader who acts as the person in charge. Actually, the person in charge of implementing the policy to reduce the use of plastic bags in traditional markets is the Mayor of Banjarmasin but operationally carried out by the Environmental Service. Marzuki, The Head of the Sanitation and Waste Management Division of the Environment office the City of Banjarmasin explained: Policy implementation activities are carried out by the Office Environmental Service in synergized with all offices within the Government of the City of Banjarmasin, including the Market Sector of the Industry and Trade Office. Then it is reported to the Mayor." Further, he explained: In carrying out socialization activities, we always follow the existing SOPs. According to the SOP flow, orders from the Head of the Office go down to the Head of Section, then to the Section Head and then to the staff. The implementors will depend on the need. For example, in market A, a Head of Division is needed, the Head of Division cooperates with the Camat and the Village Head and sometimes accompanied by Military Soldiers at the village level.Supervision is needed to ensure each activity match the plan.

The implementation of the policy to reduce the use of plastic bags, as stated in article 16 of the Banjarmasin Mayor Regulation Number 18 of 2016 that those who do the guidance and supervision are officials in charge of the environment. Related to this rule, Marzuki as the Head of the Sanitation and Waste Management Division of the Environment office, the City of Banjarmasin, explained: The office of Environmental Service of the city of Banjarmasin consists of several fields of job, each field of job has a different task. The field of the Sanitation and Waste Management has operational duties. The task of the Environmental Management Sector is to provide guidance, while the one in charge of supervising is the Supervision Sector.

Based on the bureaucratic structure factor, the socialization activities of the city of Banjarmasin government policies in reducingthe use of plastic bags have been guided by the existing SOPs. The Mayor of Banjarmasin as the person in charge of the activity carried out by the Office of the Environmental Service consists of: the Sanitation and Waste Management Division. in charge of the operational section, the Environmental Management Division is in charge of providing guidance and Supervision Division is in charge of supervising. In addition, they are also accompanied by officers from the Districts and the Villages and sometimes also from Military Soldiers at the village level.

Thru the implementation of the City of Banjarmasin Government's policy on reducing the use of plastic bags, it is hoped that it will increase public awareness to create a well-maintained and sustainable environment. Somehow public awareness and participation are needed in order to maintain and improve the preservation of a clean and healthy environment.

Obstacles

In the implementation of the Policy for Reducing the Use of Plastic Bags in the Traditional Markets in the City of Banjarmasin, found some obstacles as follows:

A. Low Public Response

The public response, both buyers and merchants, to the Government's appeals to reduce the use of plastic bags is still at the stage of low. It is proven that some of the merchants and buyers still use plastic bags every day excessively even though they have been given explanations. Therefore, it is still needed to be disseminated to the public. The existing habits are not easy to be changed. Because the use of plastic bags can make shopping easy, simple, practical, and so it has become a lifestyle. Changing people's habits takes time, effort and money.

According to Marzuki, the Head of the Sanitation and Waste Management Division of the Environment office of the City of Banjarmasin, the socialization of reducing the use of plastic bags require massive, systematic and structured activities.

Researchers obtained the information from electronic mass media that the index of Indonesian people's concern for the environment, including the people of the City of Banjarmasin, is statistically $30 \%$. This figure shows that public awareness of the environment is low.

Therefore, it is necessary for the role of all parties, both as a community and as individuals. All must work together so that the socialization of reducing the use of plastic bags is effective in achieving the expected goals.

B. Low of Public Understanding.

In the socialization activity, the Implementation Team used the form of lectures. Material delivered related to the Policy of Government the City of Banjarmasin on reducing the use of plastic bags and distributing purun baskets. The number of baskets of purun distributed for each market is not equal, depending on the width of the market. In relation to the distribution of the purun baskets, most people still do not understand that the distribution of the purun baskets is limited, not for all people in the community. Each market gets a different number of baskets of 
International Journal of Social Science (IJSS)

Vol.1 Issue.5 February 2022, pp: 601-608

ISSN: 2798-3463 (Printed) | 2798-4079 (Online)

DOI: https://doi.org/10.53625/ijss.v1i5.1302

purun, depending on the width of the market where the socialization is carried out. As an example, in Pandu Market has distributed 100 baskets of purun, while only 50 baskets of purun were distributed at TelukDalam Market.

As explained by Marzuki, the Head of the Sanitation and Waste Management Division of the Environment office, the City of Banjarmasin, that the Government role is only a stimulant or a whip because if all come from the Government funds, it will be contrary to the real purpose of socialization activities. Developing public awareness will not be achieved. Therefore, it is necessary for the participation of the entire community in implementing government programs in reducing the use of plastic bags and having a sense of responsibility to maintain a clean and healthy environment.

\section{CONCLUSION}

Actually, implementation of government policies on reducing the use of plastic bags at the traditional markets in the City of Banjarmasin based on communication, resources, dispositions and bureaucratic structures factors has been going well, but there are still obstacles on the side of the community such as the low of community response, in terms of the difficulty of changing habits people to use plastic bags. Besides, there is still a lack of public understanding in terms of the distribution of purun baskets carried out by the government.

Compared with the results of Vikalista's research (2018) with objects of modern shopping centres, supermarkets, and retail minimarkets. The difference is from the constraints of policy implementation, such as in terms of implementing (Environmental Service), which is related to the number of staff that is still lacking. Then, in terms of recipients (community) who still object to environmentally friendly bags as an alternative to plastic bags.

Recommendations for other researchers who also want to make aresearch on the implementation of plastic bag reduction policies can take objects from traditional markets that are not owned by the government or in the market belonging to the local Community.

\section{ACKNOWLEDGEMENTS}

To the parties, especially the Office Head of the Environmental Service, Head of Division and Staff at the Banjarmasin City Environmental Service Office, traders and buyers as well as government officials and other communities related to this research so that this research can be carried out.

\section{REFERENCE}

[1] Anderson, James E., (2003).Public Policymaking an Introduction, Fifth Edition, Boston :Houghton Mifflin Company

[2] Dye,ThomasR.(2002).UnderstandingPublicPolicy Tenth Edition.New Jersey:PrenticeHall.

[3] Edward III, George C., (1980).Implementing Public Policy, Washington : Congressional Quarterly, Inc.

[4] Erikson, M; Labreton, L.C; Carson, H.S; Thiel, M; Moore, C.J; Borerro, J.C; and Reiser, J (2014). $\quad$ Plastic Pollution in the world's oceans: more than 5 trilion plastic pieces wighing over 250.000 tins afloat at sea. PloS.one, 9 (12).

[5] Febriansyah (2019).InovasiBaruMengubahSampahPlastikJadiKertas yang MudahTerurai, https://tirto.id/inovasi-baru-mengubah-sampah-plastik-jadi-kertas-yang-mudah-terurai-dftk accessedon April, 19. 2019

[6] Geyer, R; Jambeck, J.R; and Law K.L. (2017). Production, use and fate all plastics ever made. Science Advances 3 (7): e1700782.

[7] Hettiaratachi, J.P.A (2007). New Trends in Waste Management: North American Percpective. Proceddings of the International Conference on Sustainable Solid Waste management, 5 - 7 September 2007, Chenna. India. Pp: $9-14$.

[8] Jambeck, J. R; Geyer, R; Wileox, C; Siegler, T.R; Perryman, M; Andrady, A; Narayan, R; Law, $\quad$ K.L (2015). Plastic Waste inputs from land into the Ocean. www.sciencemag.org. Vol. 347.

[9] Leoveanu, A.C (2013). Rationalist Model In Public Decision Making. Journal of Public Administration, Finance and Law. Issue 4/2013. Pp: 43-54.

[10] Malpass, D (2010). Introduction to Industrial Polyethylene, Catalysts, and Processes. New York: John Wiley and Sons.

[11] Matsui,Yashuhiro, et.al, 2014, Estimation of Waste generation on Traditopnal Markets in Hue City Vietnam, APLAS Ho Chi Minh, pp 1-5.

[12] Mercier, J. (2008). L'administration publique - De l'Écoleclassique au nouveau management public, Quebec, Les presses de l' Université Laval, 6e triage 
[13] Nasution, A. Z (2012). PendekatanEkosistemDalam Pembangunan Berkelanjutan. https://bangazul.com/prinsip-prinsip-pembangunan-berkelanjutan-2/ accessedMay 7 $7^{\text {th }}, 2019$.

[14] Saraswati, Amrita Nugraheni. 2018. KebijakanPublikdanRitel ModernE-JurnalEkonomidan Bisnis. ISSN : 2337-3067: 113-142

[15] Vikalista, Ellisa, 2018, ImplementasiKebijakanPeraturanWalikota Banjarmasin Nomor $18 \quad$ Tahun 2016 tentangPenguranganPenggunaankantongPlastik, Prosiding Seminar Nasional LingkunganLahanBasah Volume 3 Nomor 2 Halaman 464-470 April 2018 